\title{
CHALLENGES IN THE SURGICAL CORRECTION OF HIATAL HERNIAS AND WAYS TO OVERCOME THEM
}

Oleg Vladimirovich Galimov, Vladislav Olegovich Khanov and Dmitry Olegovich Galimov Department of Surgery and Innovative Technologies in Surgery, Bashkir State Medical University, Ufa, Russia Federation

\section{IZAZOVI U HIRURŠKOJ KOREKCIJI HIJATALNIH KILA I NAČINI NJIHOVOG PREVAZILAŽENJA}

\author{
Oleg Vladimirovich Galimov, Vladislav Olegovich Khanov i Dmitry Olegovich Galimov \\ Odeljenje za hirurgiju i inovativne tehnologije u hirurgiji, Baškirski državni medicinski univerzitet, Ufa, Rusija
}

\begin{abstract}
More than a thousand laparoscopic fundoplication operations for hiatal hernia (HH) have been performed at the Clinic of the Bashkir State Medical University over the period between 2000 and 2019 and the results of surgical treatment of 502 patients were analyzed. Our research results indicate that routine instrumental methods used in hiatal hernia diagnosis provide valuable information, however only their combined application allows us to establish the correct diagnosis in all patients. Authors propose a new original X-ray balloon method that allows to improve the quality of diagnosis of hiatal hernia significantly. Balloon X-ray allows us to establish the true dimensions of the hiatus and select the most appropriate treatment accordingly. Isolated fundoplication without plastic of esophageal opening was performed in 180 patients. Surgical correction of the hiatus was performed on 322 patients. Diaphragmcrouroraphy was carried out in 199 cases, in 123 cases mesh implants were used to support the crus of the diaphragm. In 215 cases, simultaneous surgical procedures were performed to treat multiple abdominal pathology. We studied the changes in quality of life of 100 patients with hiatal hernia before and after laparoscopic esophagofundoplication by comparing the results of the survey (questionnaires) and medical examination of the cardiac sphincter of the esophagus function. The vast majority of patients demonstrated a significant improvement in the cardiac closure function, a decrease in the frequency and severity of gastroesophageal reflux, and reduced signs of reflux esophagitis.
\end{abstract}

Keywords: hiatal hernia, surgical correction, fundoplication.

\section{SAŽETAK}

Više od hiljadu laparoskopskih operacija fundoplikacije za hijatalnu kilu (HH) izvedeno je na Klinici Baškirskog državnog medicinskog univerziteta u periodu između 2000. i 2019. godine $i$ analizirani su rezultati hirurškog lečenja 502 pacijenta. Rezultati našeg istraživanja ukazuju na to da rutinske instrumentalne metode koje se koriste u dijagnostici hijatalne kile daju vredne informacije, međutim samo njihova kombinovana primena omogućuje nam da postavimo ispravnu dijagnozu kod svih pacijenata. Autori predlažu novu originalnu metodu rendgenskog balona koja omogućava značajno poboljšanje kvaliteta dijagnoze hijatalne kile. Rendgenski snimak balona omogućava nam da utvrdimo prave dimenzije pauze i prema tome odaberemo najprikladniji tretman. Izolovana fundoplikacija bez plastifikacije otvora jednjaka izvedena je kod 180 pacijenata. Hirurška korekcija pauze izvedena je na 322 pacijenta. Krourorafija dijafragme izvedena je u 199 slučajeva, u 123 slučaja su korišteni mrežasti implantati za podršku prignječenju dijafragme. U215 slučajeva istovremeno su izvedeni hirurški zahvati za lečenje multiple abdominalne patologije. Proučavali smo promene u kvalitetu života 100 pacijenata sa hijatalnom kilom pre i posle laparoskopske ezofagofundoplikacije upoređujući rezultate ankete (upitnika) i lekarskog pregleda srčanog sfinktera funkcije jednjaka. Velika većina pacijenata pokazala je značajno poboljšanje funkcije zatvaranja srca, smanjenje učestalosti $i$ težine gastroezofagealnog refluksa i smanjene znakove refluksnog ezofagitisa.

Ključne reči: hijatalna kila, hirurška korekcija, fundoplikacija. 


\section{INTRODUCTION}

Numerous statistical studies indicate that hiatal hernias, including recurrent, complicated and acute cases, are prevalent worldwide, which makes the problem of treatment of this condition extremely relevant. Recent advances in medical technology contributed to the development of new diagnostic methods, while new medication and innovative surgical instruments significantly improved the results of treatment of patients with hiatal hernia $(1,2,3)$. At the same time, many researchers agree that, despite the wide range of available methods for correcting hiatal hernia, a single commonly accepted strategy in surgical treatment of this pathology has not yet been developed. This is primarily due to unsatisfactory results both in the immediate and long-term postoperative period $[4,6,8]$. When discussing modern methods of surgical correction of hiatal hernia, restoring the functional state of the esophageal-gastric junction and creating an anti-reflux barrier become a priority. The introduction of video-endoscopic technologies has made it possible to increase the effectiveness of anti-reflux surgical procedures $(5,7,9)$.

With the increase in the number of laparoscopic surgeries to treat hiatal hernia performed at hospitals and clinics of the city of Ufa (Russia), in recent years, doctors have often faced the problem of rising rates of unsatisfactory results associated with relapse of hiatal hernia and/or the development of pathological postoperative symptom complexes. According to our observations, many complications following the operations to correct hiatal hernia are associated with insufficient or excessive narrowing of the esophagus [5]. In order to address this issue, authors propose a new original X-ray balloon method that allows to improve the quality of diagnosis of hiatal hernia significantly and the results are presented in this paper.

\section{MATERIALS AND METHODS}

More than a thousand laparoscopic fundoplication operations have been performed at the Clinic of the Bashkir State Medical University over the period between 2000 and 2019 and the results were thoroughly monitored and analyzed.

A total of 520 patients with hiatal hernia were treated in our Clinic. There were $284(54,6 \%)$ men among them and $236(45,4 \%)$ women. The average age of patients was $49,5 \pm 5,62$ years.

The following criteria for inclusion in the study were used: patient must be over 18 years old; diagnosed with hiatal hernia; anesthetic risk assessment score (ASA) of 1-3. The criterion for exclusion from the study was the patient's signed refusal to take part in the research and/or to undergo examination. All medical procedures and examination methods, including the original methods developed by the authors, used in this study were approved by the BSMU Clinic Ethics Committee.
All patients were submitted to endoscopy and targeted biopsy, manometry, intraesophageal $\mathrm{pH}$-monitoring and Barium contrast X-ray.

The "Balloon X-ray" Method (aka traction X-ray balloonography method) developed by authors (Copyright certificate for the invention $\mathrm{N}$ 1463233) was used to evaluate the valve function of the cardia and, to establish the true dimensions of the hiatus esophagus (5). The detailed description of the original method can be found below.

The examination is performed on an empty stomach in the X-ray laboratory. The general X-ray examination of thorax and belly cavity organs in vertical position is performed. Then the patient is offered to drink approximately $100 \mathrm{ml}$ of barium. As the barium suspension passes through, the patency of the esophagus, its peristalsis, the precise shape of the His angle, rugae and the folds of the gastric mucosa are studied. An X-ray examination of the stomach at this point is focused on the key properties and functioning of the esophagus, particularly, the shape, size, stomach contents and its evacuation. Then, when hiatal hernia is suspected, a gastric probe with a radiopaque olive-shaped head and an inflatable balloon attached is inserted into the stomach. As soon as the head of the probe is actually in the stomach, $50 \mathrm{ml}$ of liquid substance is syringed in, that allows to distinguish the contours of the balloon from the gas bubble in the stomach. The inflated balloon is then pulled out with gradually increasing pressure up to $1 \mathrm{~kg}$, controlled by the dynamometer. The healthy hiatus esophagus with the size ranging within $2-3 \mathrm{~cm}$ resists the pressure applied and stops the inflated balloon from being pulled out however, the hiatus esophagus with hernia easily allows approximately $50 \mathrm{ml}$ of the balloon to pass through into the thorax followed by the stomach bottom (Fig. 1). After the X-ray examination is completed, the balloon is deflated and safely removed. Then the standard procedure of further examination is resumed.

Fig. 1. The image of the Y-patient's hiatus esophagus obtained using the Balloon X-Ray Method

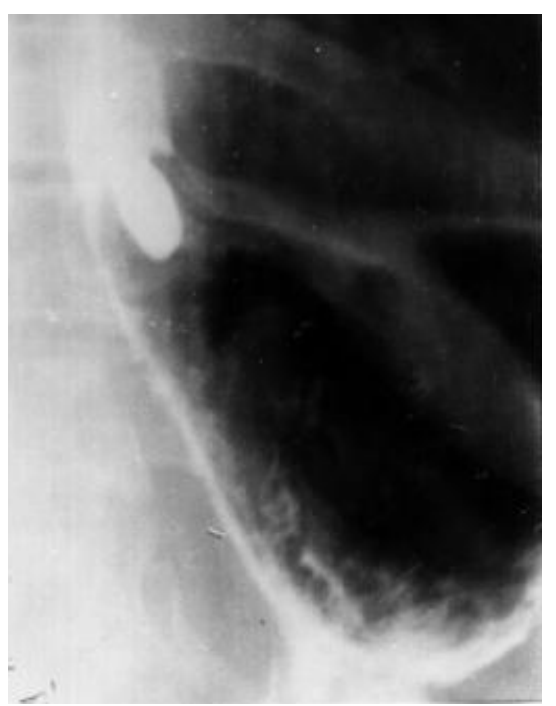




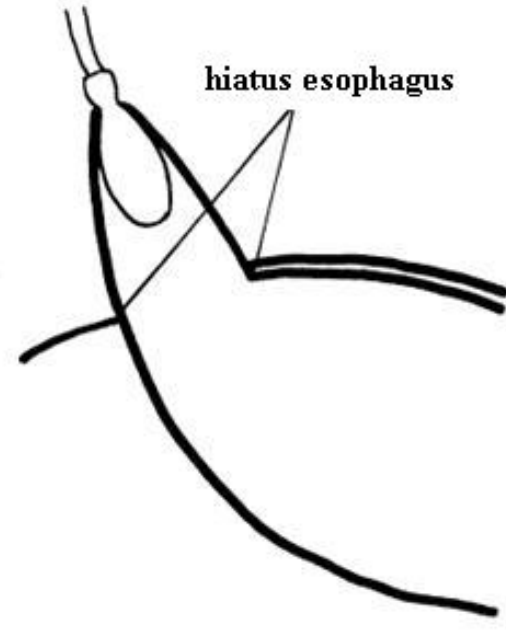

In all cases, the intraoperative size of the hiatus was measured by a special endoscopic instrument that was developed by the authors (Fig 2). The instrument has one active moving jaw with adjustable metric scale (from 0 to $9 \mathrm{~cm}$ ), that can change its angle between 0 and $90^{\circ}$. Figure 3 shows measurements of hiatus taken intraoperative.

Fig.2. Special endoscopic instrument for intraoperative measurement of the esophageal opening

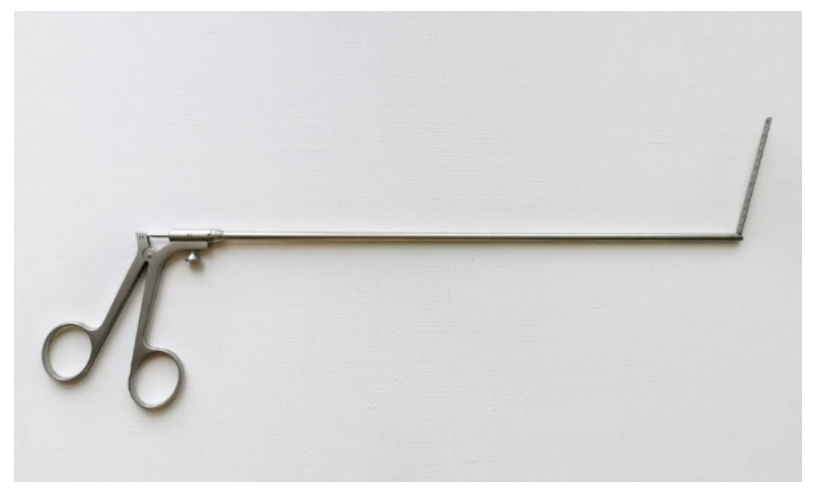

Fig.3. Intraoperative size measurement of the hiatus

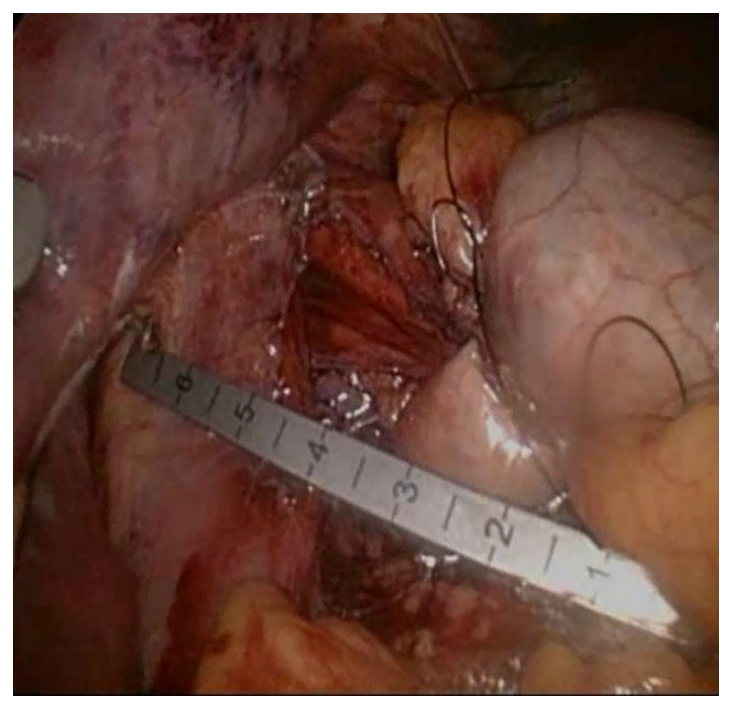

Usually, patients after laparoscopic fundoplication stayed at the clinic for 2 to 5 days and the immediate results (typically $90-95 \%$ good and very good) were observed. In addition, our study included long-term observation. Gastroesophageal Reflux Disease-Health Related Quality of Life (GERDHRQL) Questionnaire and General Health Survey (SF-36 questionnaire) were used to obtain data on the quality of life of patients with hiatal hernia after anti-reflux surgical treatment. All operated patients were asked to fill in the two questionnaires in order to obtain data on their the physical (Physical Component Summary) and psychological (Mental Component Summary) well-being in addition to the instrumental methods for studying the cardiac closure function (14).

A selective study of two-year postoperative treatment results was performed in $100(19,9 \%)$ patients with hiatal hernia in the period following 1 to 5 years after surgery, including 68 women and 32 men. The average age of the patients was $44,3 \pm 8,47$ years. The sample included 80 patients who were treated with total $\left(360^{\circ}\right)$ fundoplication (Nissen), 20 patients partial (180-270 ${ }^{\circ}$ ) fundoplication (Dor, Toupet). Correction of the esophageal opening was performed by diaphragmocrurography in 32 cases, and in 17 cases with mesh implants. The surgeons that performed operations were different. Simultaneous operations were performed in 16 cases (cholecystectomy-13, hernia-2). The long-term results were studied using the questionnaire method. 14 patients were subject to control instrumental examination. Patients were offered to assess their general well-being on a 4-point scale.

The performance and effectiveness of the methods used to diagnose hiatal hernia was evaluated based on Sensitivity and Specificity. Sensitivity, in this case, is the ability of the particular diagnostic method to detect the disease in people who actually have the disease (the probability of a positive result in people with the disease), that is, the proportion of truly positive cases. Specificity refers to the ability of a diagnostic method to distinguish patients who have not been diagnosed with the disease, from people who do not really have the disease (the probability of a negative result in people without the disease), that is, the proportion of truly negative cases that were correctly identified by the particular method. Diagnostic effectiveness or Accuracy is the average between diagnostic sensitivity and diagnostic specificity. Positive predictive value refers to the likelihood of patient actually having a hiatal hernia, when positively diagnosed by a particular method. Negative predictive value is the likelihood of the absence of $\mathrm{HH}$ when medical examination (with a particular method) produces a negative result.

The performance was calculated according to the following formulae:

Sensitivity $=\mathrm{TP} /(\mathrm{TP}+\mathrm{FN})$,

Specificity $=\mathrm{TN} /(\mathrm{TN}+\mathrm{FP})$, 
Diagnostic effectiveness (accuracy) $=($ sensitivity + specificity)/2,

\section{Positive predictive value $=\mathrm{TP} /(\mathrm{TP}+\mathrm{FP})$,}

Negative predictive value $=\mathrm{FN} /(\mathrm{FN}+\mathrm{TN})$, where $\mathrm{TP}$ were True Positive cases, patients correctly diagnosed with $\mathrm{HH}$;

TN - True Negative cases, healthy patients correctly identified as healthy;

FN - False Negative cases, patients suffering from $\mathrm{HH}$, incorrectly identified as healthyl;

FP - False Positive cases, healthy patients misdiagnosed with $\mathrm{HH}$.

\section{RESULTS}

We performed and analyzed the results of surgical treatment in 502 patients with hiatal hernia. 18 patients declined surgery in favor of conservative therapy. Laparoscopic Nissen fundoplication method was the preferred procedure at the Clinic, as the most adequate procedure that can prevent the reflux of gastric contents into the esophagus. Isolated fundoplication without esophageal opening plastic was performed in 180 patients. The expansion of the esophageal opening by more than $3.5 \mathrm{~cm}$ was considered an indication to surgery correction of hiatus. In total, additional procedures for correction of the hiatus were performed on 322 patients. Diaphragmcrouroraphy was carried out in 199 cases. In 123 cases, when crura of diaphragm were unable to sustain stiches and when the expansion of the esophageal opening was more than $5 \mathrm{~cm}$, mesh implants were used to support the crura (Fig. 4).
Fig.4. Surgical correction of hiatal hernia with a mesh implant

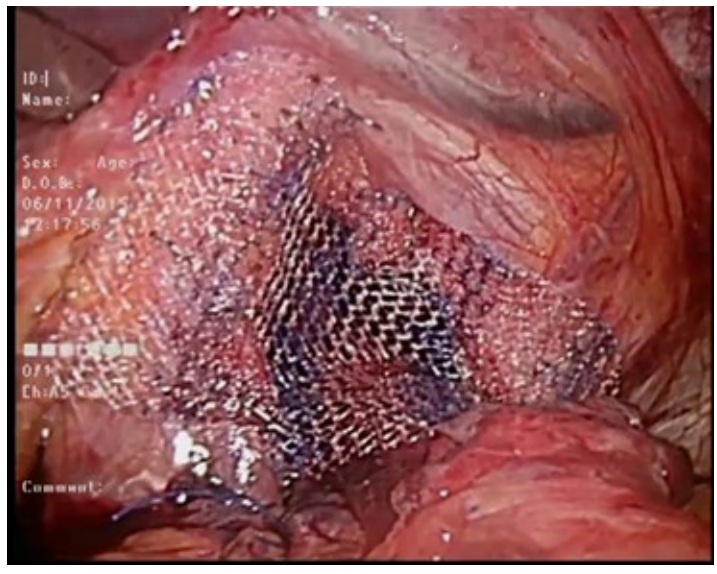

When the main pathology was combined with other abdominal diseases, requiring surgical correction, in 215 cases, simultaneous surgical procedures were performed.

The data on concomitant medical conditions and hiatal hernia-related clinical manifestations are presented in Table 1.

Table 1. Summary of symptoms, Surgical procedures and Sample Composition

\begin{tabular}{|l|c|}
\cline { 2 - 2 } \multicolumn{1}{c|}{} & Number (Percentage) \\
\hline \multicolumn{1}{|l|}{ Total number of patients: } \\
-menen & 520 \\
Age (years) & $284(54,6 \%)$ \\
\hline & $236(45,4 \%)$ \\
Concomitant diseases (number of cases, percentage): & $49,5 \pm 5,62$ \\
- duodenal ulcer & \\
- cholelithiasis, chronic cholecystitis & $162(31,2 \%)$ \\
- chronic pancreatitis & $131(25,2 \%)$ \\
- chronic violation of duodenal patency & $76(14,6 \%)$ \\
- biliary dyskinesia & $62(11,9 \%)$ \\
- Casten syndrome & $28(5,4 \%)$ \\
- Saint's triad & $21(4,0 \%)$ \\
& $15(2,9 \%)$ \\
\hline
\end{tabular}




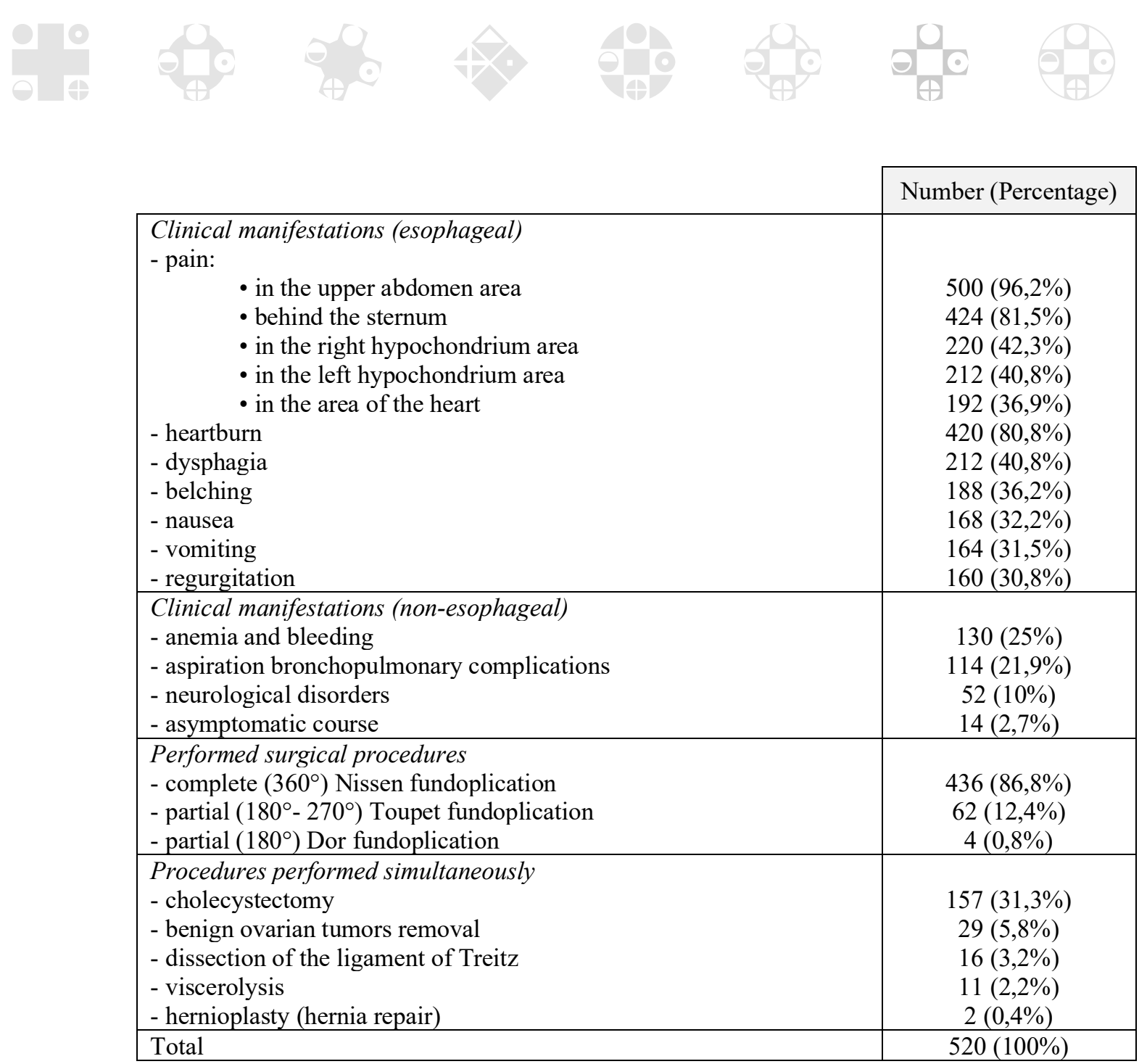

The most frequently combined procedures included cholecystectomy (157 cases), removal of benign ovarian tumors (29 cases), dissection of the Treitz ligament (16 cases), viscerolysis (11 cases), hernia corrections ( 2 cases). Intraoperative complications were diagnosed in $9(1,8 \%)$ patients. Early postoperative disfunction directly related to anti-reflux procedures were diagnosed in $73(14,5 \%)$ patients, the most common was transient dysphagia $39(7,7 \%)$ cases. Reactive serous pleurisy occurred in $8(1,6 \%)$ cases. These complications were transient in nature and were corrected by conservative therapy.

The preoperative Balloon X-ray examination results always matched the intraoperative measurements. The procedure proved to be convenient and effective, no complications ever occurred during and/or after the Balloon X-ray examination. In addition, the technique does not require any expensive equipment.
The results show that the reliability of the sliding hiatal hernias diagnosis increased to $95,5 \%$ particularly for hiatal hernias where the esophageal opening of the diaphragm increased to between 3.5 and $7.5 \mathrm{~cm}$. Thus, the Balloon X-ray method developed at the Clinic was proven effective in our clinical practice and today is mandatory before performing surgery for hiatal hernia.

Our results presented in Table 2 demonstrate that routine instrumental methods used in hiatal hernia diagnosis provide valuable information, however only their combined application allows us to establish the correct diagnosis in all patients. 
Table 2. Comparison of methods of hiatal hernia diagnosis.

\begin{tabular}{|l|c|c|c|c|c|}
\hline & Sensitivity & Specificity & Accuracy & $\begin{array}{c}\text { Positive predic- } \\
\text { tive value }\end{array}$ & $\begin{array}{c}\text { Negative pre- } \\
\text { dictive value }\end{array}$ \\
\hline X-ray & $78,9 \%$ & $25 \%$ & $51,96 \%$ & $83,4 \%$ & $80,01 \%$ \\
\hline Esophagogastroduodenoscopy & $92,6 \%$ & $83,3 \%$ & $87,95 \%$ & $98,8 \%$ & $58,3 \%$ \\
\hline $\begin{array}{l}\text { pH-monitoring, } \\
\text { Esophagomanometry }\end{array}$ & $89,5 \%$ & $25 \%$ & $57,25 \%$ & $85 \%$ & $66,6 \%$ \\
\hline Balloon X-ray & $94,7 \%$ & $71,4 \%$ & $83,05 \%$ & $97,8 \%$ & $50 \%$ \\
\hline
\end{tabular}

As for two-year postoperative patient well-being results, the complete survey data was obtained from 84 patients of 100 who took part in the research. Patients were offered to assess their general well-being on a 4-point scale. $7(8,3 \%)$ patients reported it as Excellent, $45(53,6 \%)$ as Good, 24 $(28,5 \%)$ Satisfactory and $8(9,5 \%)$ noted unsatisfactory results.

When patients self-assessed their state of health according to the GERD-HRQL questionnaire, a statistically significant restoration of the cardiac closure function according to manometric data and the DeMeester indicator was noted. At the same time, in some patients with excellent and good results, gastroesophageal reflux and reflux esophagitis in the lower third of the esophagus was observed according to the daily intra-esophageal $\mathrm{pH}$-meter and esophagogastroduodenoscopy $(23,81 \pm 4,65 \%)$. Self-reported quality of life of patients, according to the SF-36 questionnaire, increased during the 1 st and 2 nd year after surgery compared with preoperative values. To the question of whether preoperative complaints disappeared, 48 patients $(57,1 \%)$ answered affirmatively, whereas $36(42,9 \%)$ patients noted slight presence of pathological symptoms, which are often observed after various types of esophagus cardiac sphincter correction.

When asked if patients were generally satisfied with the results of surgical treatment, $52(61,9 \%)$ patients answered "Yes" while $32(38,1 \%)$ of patients answered "No". Moreover, all patients who underwent combined surgical procedures were in the group satisfied with the results of surgery. Of 14 patients submitted for control instrumental examination, the majority $(78,7 \%)$ showed no deviations from the normal, only $2(14,2 \%)$ patients were diagnosed with esophagitis, and $1(7,1 \%)$ patient, earlier treated with partial Toupet fundoplication, upon X-ray examination showed early signs of a relapse of hiatal hernia.

\section{DISCUSSION}

Modern X-ray technology in a traditional medical examination does not always allow one to identify reflux esophagitis and sliding hiatus hernias, as well as to differentiate them from an ampoule or diverticulum of the esophagus. Thus, X-ray does not provide sufficient evidence to form an informed medical opinion as to the severity of the pathological process, in particular, assess the size of the hernia defect $(10,11)$.
The "Balloon X-ray" Method (aka traction X-ray balloonography method) developed by authors increases the HH diagnostics effectiveness; which allows us to evaluate the valve function of the cardia and, most importantly, to establish the true dimensions of the hiatus esophagus (5).

Moreover, precise information on the hernia defect size is very valuable as it helps in selection of the hiatal hernia treatment and the most appropriate technique for the operation if needed. Knowing the exact dimensions of the defect, implants can be prepared, if necessary, according to the specified size.

As many authors point out $(12,13)$, every instrumental method used in hiatal hernia diagnosis provides valuable information. Esophagogastroduodenoscopy is one of the most reliable methods for the diagnosis of esophagitis, which allows to visually examine the condition of the mucous membrane of the esophagus and stomach, as well as to obtain biopsy samples for further histological examination. Manometry and intraesophageal $\mathrm{pH}$-monitoring enable assessment of the cardiac sphincter tone and help to identify the diseases of the esophageal-gastric transition in the functional phase; help to reliably assess the disease dynamics and the effectiveness of the treatment. None of these procedures should be treated as rival diagnostic methods but only as complementing each other.

\section{CONCLUSION}

Our research results show that routine instrumental methods used in hiatal hernia diagnosis provide valuable information, however only their combined application allows us to establish the correct diagnosis in all patients. We propose a new original X-ray balloon method that allows to improve the quality of diagnosis of hiatal hernia significantly. Balloon $\mathrm{X}$-ray allows us to establish the true dimensions of the hiatus and select the most appropriate surgical treatment accordingly. The long-term results studied by us did not reveal any significant difference in the postoperative subjective sensations of patients between surgical procedures (total or partial fundoplication). It is suggested that the results of operations in patients with hiatal hernia depend largely on a thorough selection of patients for intervention. Indications to surgery should be based on sufficient data obtained from preoperative clinical and instrumental examination, including potential concomitant pathologies. 


\section{LITERATURE}

1. Cáterin Arévalo MD., Rubén D., Luna MD., Carlos A. et all. Literature review: a surgeon's view of recurrent hiatal hernia. Rev. Col. Gastroenterol. 2015; 30(4); $443-451$

2. Dellemagne B, Perretta S. Twenty years of laparoscopic fundoplication for GERD. World $\mathrm{J}$ Surg. 2011;35(7):1428-35. doi: 10.1007/s00268-011-1050-6.

3. Yu HX, Han CS, Xue JR, Han ZF, Xin H. Esophageal hiatal hernia: risk, diagnosis and management. //Expert Rev Gastroenterol Hepatol. 2018 Apr;12(4):319-329. doi: 10.1080/17474124.2018.1441711.

4. 4.Fuchs KH, Babic B, Breithaupt W, Dallemagne B et al. EAES recommendations for the management of gastroesophageal reflux disease. Surg Endosc. 2014;28(6):1753-73. doi: 10.1007/s00464-014-3431-z.

5. Galimov OV, Khanov VO et al. Creative surgery for hiatal hernia. Khirurgiya. Zhurnal imeni N.I. Pirogova 2017; 7; 30-32.

6. Le Page PA, Furtado R, Hayward M, Law S et al. Durability of giant hiatus hernia repair in 455 patients over 20 years Ann R Coll Surg Engl. 2015; 97(3):188-93. doi: 10.1308/003588414X14055925060839

7. Tam V, Winger DG, Nason KS A systematic review and meta-analysis of mesh versus suture cruroplasty in laparoscopic large hiatal hernia repair Am J Surg.2016; 211(1):226-38. doi: 10.1016/j.amjsurg.2015.07.007.

8. Mayor MA, Fernando HC. Endoluminal approaches to gastroesophageal reflux disease. Thorac Surg Clin. 2018;28(4):527-532. https://doi.org/10.1016/j.thorsurg. 2018.07.008

9. Watson DI, Thompson SK, Devitt PG et al. Laparoscopic repair of very large hiatus hernia with sutures versus absorbable mesh versus nonabsorbable mesh. A randomized controlled trial Ann Surg. 2015;261(2):282-9. doi: 10.1097/SLA.0000000000000842.

10. Weyhe D, Uslar V, Kühne J, Kluge A. Hiatus hernia: Standards and controversies in diagnostics and treatment. //Chirurg. 2019 Apr;90(4):331-348. doi: 10.1007/s00104-019-0932-2.

11. Siegal SR, Dolan JP, Hunter JG. Modern diagnosis and treatment of hiatal hernias.//Langenbecks Arch Surg. 2017 Dec;402(8):1145-1151. doi: 10.1007/s00423-0171606-5.
12. Seif Amir Hosseini A, Uhlig J, Streit U, Uhlig A, Sprenger T, Wedi E, Ellenrieder V, Ghadimi M, Uecker M, Voit D, Frahm J, Lotz J, Biggemann L. Hiatal hernias in patients with GERD-like symptoms: evaluation of dynamic real-time MRI vs endoscopy. //Eur Radiol. 2019 Dec;29(12):6653-6661. doi: 10.1007/s00330-019-0628 4-8.

13. 13.Tatum JM, Samakar K, Bowdish ME, Mack WJ, Bildzukewicz N, Lipham JC. Videoesophagography versus Endoscopy for Prediction of Intraoperative hiatal hernia size. //Am Surg. 2018 Mar 1;84(3):387-391.

14. V.I. Oskretkov, V.A. Gankov, A.R. Andreasyan, M.A. Ovsepyan The comparison of a questionnaire survey and special methods of examination in patients with gastroesophageal reflux disease Endosurgery.2018;6:2932. 